\title{
Parameters Affected Corrosion and Mechanical Properties of Al-Brasses
}

Tatiana Liptáková ${ }^{1}$, Martin Lovíšek ${ }^{1}$, Branislav Hadzima ${ }^{2}$

${ }^{1}$ University of Žilina, Faculty of Mechanical Engineering, Department of Material Engineering, Univerzitná $\quad 8215 / 1$, 01026 Žilina, Slovakia. E-mail: tatiana.liptakova@ @stroj.uniza.sk, martin.lovisek@fstroj.uniza.sk

${ }^{2}$ Research Centre of the University of Žilina, Univerzitná 8215/1, 01026 Žilina, Slovakia. E-mail: branislav.hadzima@rc.uniza.sk

The Al-brasses are considered corrosion resistant technical materials especially used in pipe systems in energy industry. They are mostly exposed to flowing liquids environments where they are loading chemically and mechanically and their lifetime in practice condition quite vary. The aim of our research work is to compare corrosion and mechanical properties of four Al-brasses from various producers. The Al-brasses have very similar chemical composition but differ in microstructure, surface state what affect their corrosion and mechanical behavior. By chosen experimental methods and analyses the effect of the mentioned parameters are investigated.

Keywords: Al-brasses, Microstructure, Surface, Corrosion potential, Microhardness

\section{Acknowledgement}

The research is supported by European regional development fund and Slovak state budget by the project "Research centre of University of Žilina”, ITMS 26220220183.

\section{References}

[1] CALLCUT, V. (2005). The brasses: properties \& aplications. 2. ed. Hemel Hepstead: CDA Publication, no. 117, p. 37, 45.

[2] ČERNÝ, M. et al. (1984). Korozní vlastnosti kovových konstrukčních materiálů. 1. vyd. Praha: SNTL - Nakladatelství technické literatury. 264 s. ISBN 04-239-84

[3] BABOIAN, R. (2005). Corrosion tests and standards: Aplication and interpretation. 2. ed. ASTM International. 882 s. ISBN 978-1-60119-437-4

[4] ABOUSWA, K., ELSHAWESH, F., ELRAGEI, O., ELHOOD, A. (2007). Corrosion investigation of Cu-Ni tube desalination plant, Desalination 205, 140-146.

[5] CHEN, J.L., LI, Z., ZHAO, Y.Y. (2009). Corrosion characteristic of Ce Al brass in comparison with As Al brass, Materials and Design 30, 1743-1747

[6] EL-MAHDY, G. A., et al. (2013). Brass Corrosion under a single droplet of $\mathrm{NaCl}$, Int. J. Electrochem. Science, 8 , p. 9858-9867.

[7] POMENIC, L. (2006). Electrochemical behaviour of Al-Brass in seawater. In 10th International Research/Expert Conference: „Trends in the development of machinery and associated technology“.

[8] SATO, S., NAGATA, K. (1978). Factors Affecting Corrosion and Fouling of Metal Condenser Tubes of Copper Alloys and Titanium. Sumitomo light metal technical REPORTS, VOL. 19, NOS. 3 AND 4, P.83, 1978.

[9] BIANCHI, G., FIORI, G., LONGHI, P., MAZZA, F. (1978). Horse shoe corrosion of copper alloys in flowing sea water: mechanism, and possibility of cathodic protection of condenser tubes in power stations. Corrosion 34, 396406.

[10]CALLISTER, W.D., RETHWISCH, D.G. (2010). Materials Science and Engineering: An Introduction. John Wiley and Sons; 8th edition. 992 p. ISBN 978-0-470-41997-7.

[11]CARVALHO, M.L. (2014). Corrosion of copper alloys in natural seawater - Effects of hydrodynamics and pH, Dissertation thesis.

[12]LIPTAKOVA, T., HADZIMA, B. (2011). Porovnanie vlastností mosadzí typu CuZn20A12. Report, USI MOS 11, Žilina.

[13]STACK, M.M., CORLETT, N., ZHOU, S. (1997). A Methodology for the Construction of the Erosion-corrosion Map in Aueous Environment. In: Wear 203-204, 474-488. 